\title{
IMPLEMENTATION OF ONLINE LEARNING DURING COVID-19 ON STUDENTS IN ACCOUNTING DEPARTMENT POLIMDO
}

\author{
Kiet Tumiwa, Jolly Turangan, Ruhiyat, Roslina H.S.D. Limpeleh \\ Department Of Accounting, Polytechnic of Manado Country \\ DOI: 10.31364/SCIRJ/v9.i09.2021.P0921875 \\ http://dx.doi.org/10.31364/SCIRJ/v9.i09.2021.P0921875
}

\begin{abstract}
Circular of the Ministry of Education and Culture No. 4 of 2020, point 2 regarding the learning system without face to face directly between lecturers and students but carried out online using the internet network. Every lecturer must ensure that teaching and learning activities run well and regularly according to the Semester Lesson Plan. Lecturers can study together at the same time using personal computers, groups on social media, such as WhatsApp (WA), telegram, Instagram, zoom applications or other media as a medium for carrying out the learning process. The purpose of this study was to determine the implementation of online learning during covid 19 for students in the Polimdo accounting department. The method used in this research is descriptive qualitative method, namely understanding the object under study, including information about the main phenomenon that is explored in depth. Data analysis techniques are carried out by searching and systematically compiling data collection, data reduction, presentation and data and conclusions through observations and interviews in the field. The results of the study show that online learning is very effective, in order to break the chain of the spread of the Covid-19 virus. However, there are some students who say that online learning is less effective / lazy because the internet network is often not good, so the lessons given by the lecturers are difficult to understand. Then, with online learning, students feel more independent, creative, save parents' finances, and online learning is also a form of success in creating social distancing and minimizing crowds which are considered to have a major influence on the spread of COVID-19. As for other supporting factors, namely students feel that the free quota provided by the government every month is very helpful, even though sometimes the quota is not enough to use online lectures.
\end{abstract}

Keywords: Polimdo, Student, Online Learning

\section{INTRODUCTION}

The Covid-19 pandemic in Indonesia is part of the ongoing coronavirus disease 2019 (Covid-19) pandemic around the world. This disease is caused by severe acute respiratory syndrome coronavirus 2 (SARS-CoV-2). The first positive case of Covid-19 in Indonesia was detected on March 2, 2020, when two people were confirmed to have contracted it from a Japanese citizen. On April 9, the pandemic had spread to 34 provinces with DKI Jakarta, West Java and Central Java as the provinces most exposed to the corona virus in Indonesia. Covid-19 has a direct impact on all areas of community movement, from restrictions on personal activities to large-scale social activities. In connection with the impact of Covid-19, the students also felt it because of the delay in the face-to-face learning process on campus. Therefore, the government issued a circular letter from the Ministry of Education and Culture No. 4 of 2020, the second point was conveyed related to learning from home or the online learning system.

The online learning system is a learning system without face to face directly between lecturers and students but is carried out online using the internet network. Every lecturer must ensure that teaching and learning activities run well. The learning system is implemented through a personal computer or laptop device that is connected to an internet network connection. Lecturers can study together at the same time using groups on social media, such as WhatsApp (WA), telegram, Instagram, zoom applications or other media as a medium for carrying out the learning process.

This online learning process has many impacts, ranging from positive impacts to negative impacts. In this online learning, lecturers are required to prepare for learning as well and as creatively as possible in providing a material. Especially among students because the online learning process is not easy. In this online learning process, it does not only involve lecturers and students, but also parents are required to be involved in this online learning process. Parents with a good financial background may be very adaptable in the online learning process. However, parents with minimal financial background may find it very difficult to adapt to the online learning process because they have to buy learning media, such as a good laptop or cellphone. A weak internet network is also one of the factors that can hinder the online learning process because this online learning process will run smoothly if the quality of the internet network is smooth and stable. This online learning process also makes it difficult for lecturers to deliver learning materials because not all students are enthusiastic about participating in the online learning process.

The enthusiasm of students to take part in online learning, according to several students, is a problem with the strength of the internet network and communication tools, such as mobile phones, computers or laptops that have features that can match the 
applications set by the Polimdo institution. As a result, some students have difficulty understanding the subject matter given by the lecturer. Even the lecturers have difficulty in measuring the extent to which these students understand the material given. Based on the background above, the researcher formulated the problem formulation as follows: "How is the Implementation of Online Learning During Covid 19 for Students in the Polimdo Accounting Department"?

\section{RESEARCH METHODS}

Research conducted by researchers, namely qualitative research. Qualitative research is a type of research whose findings are not obtained through quantification procedures, statistical calculations, or other forms of methods that use numbers. The principle of qualitative research is to understand the object being studied in depth, including information about the main phenomena explored in research, research participants and research locations. This research was conducted at the Department of Accounting Polimdo, which is located in the village of Buha, District Mapanget, North Sulawesi. Sources of data obtained can be in the form of primary data sources and secondary data sources. Primary data sources, namely data directly collected by researchers from the first source. The primary data sources in this study were 6 students majoring in Polimdo Accounting. Secondary data sources, namely data directly collected by researchers as a support from the first source. Data collection procedures used in this study, namely: observation, interviews and documentation. Data analysis is the process of systematically searching and compiling data obtained from interviews, field notes, and documentation, by organizing the data into categories, describing them into units, synthesizing, compiling patterns, choosing which ones are important and which will be. learned, and draw conclusions so that they are easily understood by themselves and others. In this qualitative research, the researcher uses descriptive data analysis techniques in analyzing the research data obtained from the process of systematically searching and compiling data obtained from observations, interviews, and the field, namely: data collection, data reduction, data presentation, conclusions and verification.

\section{DISCUSSION}

\section{A. Research findings}

Based on the results of research conducted by researchers on students in the Polimdo accounting department regarding the implementation of online learning during Covid 19 for students in the Polimdo accounting department, they are as follows:

\section{Online Learning}

Online learning (on the network) is a learning system without face to face directly between lecturers and students. Lecturers must ensure that teaching and learning activities continue, even though students are at home. The solution is that lecturers are required to be able to design learning media as innovations by utilizing online learning.

Online learning used in the Polimdo accounting department during the covid-19 pandemic, namely distance or online learning that has been carried out from mid-March 2021 until now. This distance learning is carried out in accordance with the recommendation of the Minister of Education and Culture of the Republic of Indonesia regarding Circular Letter Number 4 of 2020, concerning the Implementation of Education Policies in the Emergency Period for the Spread of Corona Virus Disease (COVID-19) in order to break the chain of the spread of the Covid-19 virus. The learning model applied by the accounting department is using BBB e-learning, zoom, google class room, google meet, written and practical assignments, as described in interviews conducted by researchers with students in the seventh semester of GB applied.

GB revealed that "online learning in the Polimdo accounting department starts from mid-March 2020 until now, and will continue to be carried out until the end of the odd semester in December 2021, considering the covid 19 pandemic is still everywhere. The online learning model used by lecturers is using BBB e-learning, zoom, google class room, google meet, written assignments, and practice. In practice, students are assigned to make a work that is videoed on a youtube link and the results are sent to the course lecturer. In my opinion (GB) what course lecturers have assigned has been effective and in accordance with the current state of the COVID-19 pandemic." It's different with applied fifth semester students

(AG) said about online learning "the limitations of the online learning process, I consider it ineffective, and the explanation of the material is inadequate. The lecturer explained that not everyone could understand. Many times there are network disturbances so that the voice of the lecturer's explanation is not heard clearly, and also when studying online, students are required to do the assignments given with a time limit that often collides with other courses, so that students are often late in submitting assignments. There are also learning media provided by the campus, namely E-learning which is often interrupted, submitted assignments and absences are often erased, lecturers' voices are often not heard / broken, and want to activate the camera when the lecturer takes pictures, the server is not sufficient for camera is activated.

The learning implementation plan model used in online learning during the Covid-19 pandemic in the Polimdo accounting department, namely the semester learning plan in accordance with government recommendations, as explained by the MB taxation D3 semester V student in the interview, as follows: The assessment or evaluation process carried out by lecturers, 
namely when giving written assignments and practical assignments to students. As explained by MB in the interview, as follows:

We students are given the task of doing questions, making a work, or practicing a scene in the learning material by making a video, and uploading it to youtube, then the link for the assignment is sent to the lecturer concerned. Written assignments given by the lecturer through the application are also collected through the application in accordance with the advice of the course lecturer.

Through this online learning, it is hoped that students can study as usual and will not miss lecture material, as well as more flexible time. However, online learning is not fully welcomed by students because there are some students who think online learning is more difficult, compared to ordinary learning. The biggest obstacles are network constraints, and the level of understanding of the material that is considered better if conducting face-to-face lectures, and also not all lecturers and students are ready to operate the online learning system quickly, including preparing lecture materials digitally.

\section{Barriers to the Implementation of Online Learning for Students in the Polimdo Accounting Department}

Online learning cannot be separated from the internet network. Internet network connection is one of the obstacles faced by students whose places of residence are difficult to access the internet, especially those students who live in rural, remote and underdeveloped areas. Even if someone uses a cellular network, sometimes the network is unstable because of the geographical location that is still far from the reach of the cellular signal. This is also a problem that often occurs in students who take part in online learning, so it is not optimal and can be said as an inhibiting factor in the online learning process.

The inhibiting factor in implementing online learning for students in the accounting department of Polimdo. The fifth semester student of applied NL revealed,

"The lack of effectiveness in the online learning process. The lecturer explained that not all lessons could be understood well because there were many times when there were internet network disturbances. With the disruption of the internet network, the voice of the lecturer's explanation was not heard clearly so there was a lack of confidence to ask questions. Then, when studying online, students are required to do the assigned tasks with a time limit that often collides with other courses, so that students are often late in submitting assignments. As for the learning media provided by the campus, namely E-learning Big Blue Botton (BBB), they often experience problems. Assignments and absences that have been submitted are often lost, and the problem is when using BBB e-learning for face-to-face, when you want to activate the camera, the server is not sufficient for the camera to be activated."

Another inhibiting factor in implementing online learning in the accounting department, namely the fifth semester student of taxation, GK revealed that:

"Online learning I feel lazy / decreased interest in learning because the lessons given are difficult to understand, and the network does not support it".

\section{Online Learning Support for Students in the Polimdo Accounting Department}

The good impact that can be seen from this online learning is that one of them is saving time. Students no longer need to spend time on campus. It can be said, with online lectures, some students can manage their time better and are more creative and independent than before.

MB said, "learning at home online makes me more independent and creative, and online learning is a form of success in creating social distancing and minimizing crowds which are considered to have a big influence on the spread of COVID-19. As for other supporting factors, namely that we are given a free quota by the government every month, even though sometimes the quota is not enough for us to use for college. However, we have been very helpful." Student J also revealed that online learning can save money. Usually to campus must pay for transportation and food. However, with online learning, I am grateful that I can save my finances"

\section{B. Analysis of Research Results}

After the data is presented on the facts of the findings above, the follow-up of this research, namely the analysis of the collected data using descriptive qualitative research methods in detail.

\section{Online Learning at Polimdo Akuntansi Accounting Department}

Online learning or distance learning is learning without face to face directly between lecturers and students. Online learning or distance learning is considered very effective, in order to break the chain of the spread of the Covid-19 virus. The right learning model, which is given by lecturers to students, especially students majoring in accounting at Polimdo, is a learning model that can be understood by students. The learning model applied by the lecturer is considered to be quite effective. However, there are some students who also say that online learning is less effective because the internet network is not good, so often the voices of lecturers cannot be heard.

The online learning provided by the lecturer is in accordance with the semester learning plan, namely in the form of written and practical assignments, as explained by one student: "Online learning used, namely e'learning bbb, google class room, google meet, google classroom, assignments writing and practice. In practice, students are assigned to make a work that is videoed and the results are shown and then sent to the course lecturer.

Lecturers of courses make Project Based Learning in semester learning plans, the aim is that students are able to understand technology more deeply, and work according to the courses given. To produce video courses, which can increase student motivation and effectiveness, the development of student videos must pay attention to the following characteristics and 
criteria:

i. Messages must be clear and independent

Student video media can give messages more meaningfully and information can be received in its entirety and can be stored in long-term memory. The videos developed do not depend on other teaching materials or do not have to be used together with other teaching materials.

ii. Easy to understand language and represent

Information in video media made by students must use simple language, easy to understand, and use common language. The material must be truly representative, for example, simulation or demonstration material. Basically, both social and science course material can be made into video media.

Iii, Visualization with media

The material is packaged in multimedia, including text, animation, sound, and video according to the demands of the material. The materials used are applicable, processed, difficult to reach, dangerous if directly practiced, have a high level of accuracy

iv. Using high resolution quality

Display in the form of graphics, video media made with digital engineering technology, high resolution but support for every computer system spec.

v. Can be used classically or individually

Learning videos can be used by students individually, not only in school settings, but also at home.

Project based learning is required for students to make videos. Video media is able to attract students' attention, increase students' imagination power, increase critical thinking power and trigger students to participate more and be enthusiastic, so that later students can be more active in the learning process. In addition, video media has a function to present something concrete, even though it is not in physical form. Assessment is a very important part in the world of education, because assessment is an evaluation material during the learning process. Evaluations are carried out in the online learning process, namely by giving assignments to students in oral, written or video form.:

Assessment of video media by lecturers to students can be done through student creativity, student activity during online learning, and so on. Assessment can be carried out in various forms, not only assessing knowledge but also assessing students' skills, activity and creativity according to the material the teacher provides. Arifin (2013: 5) argues that evaluation is a process not a result. The results obtained from evaluation activities are a description of the quality of something, both concerning value or meaning. While the activity to arrive at the value and meaning is evaluation.

\section{Barriers to the Implementation of Online Learning in the Polimdo Accounting Department}

An important key in the success of this online learning is the internet network. Therefore, communication between students and lecturers in the online learning process must be better. Students must be frequently motivated to stay motivated to participate in the online learning process. The expression of one student, sometimes becomes lazy because there are frequent internet network disturbances which result in the lecturer's explanation of the course being not understood, making online learning itself less than optimal. Students feel that face-to-face learning is better and more effective than online learning. Therefore, the lecturer must make a semester lesson plan so that students understand the topic that will be given by the lecturer before the lesson is given.

Semester lesson plans are very important things to be implemented for students in the accounting department of Polimdo. Without planning, lecturers may experience difficulties in realizing the goals to be achieved. With the semester learning plan, work can be more focused and clear. Online semester learning plans can affect success in carrying out the online learning process. The success of the online learning process can be seen from the percentage of students' enthusiasm in participating in online learning.

Online learning, lecturers are required to be creative and innovative in managing learning materials/materials in order to attract enthusiastic students to be more enthusiastic and interested in participating in online learning. Structured learning is a set of actions designed for the learning process of students by considering internal events that take place in students. A successful learning process requires certain techniques, methods, and approaches according to the characteristics of the objectives, students, materials and teaching resources, so the right strategy is needed (Nurmin Lasapa et al, 2017).

Structured learning is a form of systematic learning, in the implementation of structured learning, the lecturer conveys the goals to be achieved in the process. It can also be said that structured learning is learning that is oriented towards the goals to be achieved (Ummu Nadifah, 2018).

\section{Supporting Online Learning in Polimdo Akuntansi Accounting Department}

The supporting factors for online learning used by Polimdo lecturers, namely using BBB e-learning, zoom, google class room, google meet, are a means of technological advancement that helps students and lecturers in the online learning process. Online learning is certainly different from implementing face-to-face learning in the classroom. In implementing online learning, lecturers must of course be creative in using technology and be able to motivate students because lecturers are the key to the success of the online learning process itself. Even in online learning, a stable signal quality and adequate internet quota are needed to support the success of online learning.

As for the supporting factors in online learning, as stated by one student, "learning at home online makes students more independent and creative, and online learning is a form of success in creating social distancing and minimizing crowds which are considered to have a major influence on the spread of COVID-19. As for other supporting factors, namely that we are given a free quota by the government every month, even though sometimes the quota is not enough for us to use for college. However, we

www.scirj.org

(C) 2021, Scientific Research Journal

http://dx.doi.org/10.31364/SCIRJ/v9.i09.2021.P0921875

This publication is licensed under Creative Commons Attribution CC BY. 
feel that the government has helped us." Other students also revealed that online learning can save money. Usually to campus must pay for transportation and food. However, with online learning, I am grateful that I can save my parents' finances."

\section{CONCLUSION}

Based on the results of research and discussion in the previous chapter, it can be concluded that:

1. Online learning is considered very effective, in order to break the chain of the spread of the Covid-19 virus

2. The learning model applied by the lecturer is considered to be quite effective. However, there are some students who also say that online learning is less effective/become lazy because the internet network is often not good, so the lessons given by the lecturers are difficult to understand

3. BBB e-learning, zoom, google class room, google meet, are a means of technological advancement that supports students and lecturers in the online learning process in the Polimdo accounting department.

4. Students feel more independent and creative, and online learning is a form of success in creating social distancing, and minimizing crowds which are considered to have a major influence on the spread of COVID-19. As for other supporting factors, students feel that the free quota provided by the government every month is very helpful, even though sometimes the quota is not enough for us to use for college

5. Online learning can save money, usually you have to pay for transportation and meals to campus. However, online learning can save parents' finances.

\section{REFERENCES}

A. Kurniawati, et al. 2013. Implementation of Video Analysis Assignment Method on Cognitive, Social and Moral Development Material. Indonesian Journal of Natural Science Education, Volume 2, Number 2.

Allen, Michael. 2013. Michael Allen's Guide to E-learning. Canada: Jonh Willey \& Sons.

Arifin, Zainal. 2013. Learning evaluation. Bandung: Remaja Rosdakarya.

Asnawir dan Basyiruddin Usman. 2002. Learning model. jakarta: Ciputat Pers.

Chandrawati, Sri Rahayu. 2010. Utilization of E-Learning in Learning. Journal of Educational Horizons, Volume 8, Number 2.

Daryanto dan Raharjo Muljo. 2012. Innovative learning model. Yogyakarta: Gava Media.

Dewi, Wahyu Aji Fatma. 2020.. The Impact of Covid-19 on the Implementation of Online Learning in Elementary Schools. Journal of Educational Sciences, Volume 2, Number 1.

Effendi, Empy dan Hartono Zhuang. 2005. e-Learning Konsep dan Aplikasi. Yogyakarta: Andi.

Haerul, Haedar Akib dan Hamdan. 2016. Implementation of the Makassar Non Rantasa (MTR) Program Policy in Makassar City. Jurnal Administrasi Publik, Volume 6, Nomor 2.

Hamdani. 2011. Teaching and Learning Strategy. Bandung: CV Pustaka Setia.

Hamdani, Acep Roni dan Asep Priatna. 2020. The Effectiveness of the Implementation of Online Learning (Full Online) During the Covid-19 Pandemic at the Elementary School Level in Subang Regency. PGSD STKIP Subang Scientific Journal, Volume 6, Number 1.

Isjoni. 2013. Cooperative Learning: Effectiveness of Innovative Learning. Bandung: Alfabeta

Munir. 2009. Distance Learning Based on Information and Communication Technology. Bandung: Alfabeta.

Riyanda, Afif Rahman et al. 2020. Evaluation of the Implementation of the Online Learning System of the Faculty of Teacher Training and Education, University of Lampung. Journal of IKRA-ITH Humanities, Volume 4, Number 1.

Saefuddin, Aziz, Ika Berdiati. 2014. Effective learning. Bandung: Remaja Rosdakarya.

Sukardi, Ismail. 2013. Modern Learning Models. Palembang: Tunas Gemilang Pers.

Trianto. 2010. Integrated Learning Model. Jakarta: Bumi Aksara. 